
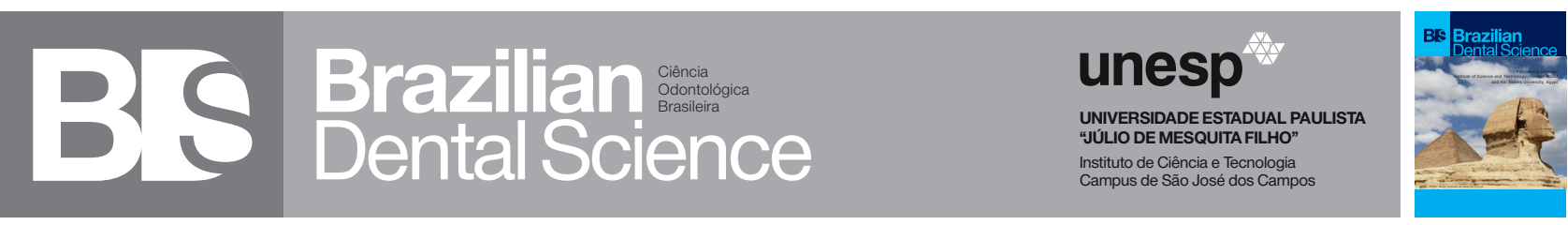

\title{
Oral and periodontal features of autosomal recessive syndromes: a tabular review
}

Características oral e periodontal de síndromes autossômicas recessivas: uma revisão tabular

Sesha REDDY ${ }^{1}$, Kharidhi Laxman VANDANA ${ }^{2}$, Shishir Ram SHETTY ${ }^{3}$

1 - Department of Periodontics - College of Dentistry - Gulf medical university - Ajman - United Arab Emirates.

2 - Department of Periodontics - College of Dental Sciences - Davangere - India.

3 - Oral Medicine and Radiology - College of Dentistry - Gulf Medical University - Ajman - United Arab Emirates.

\begin{abstract}
Objective: To systematically review the data and results of case reports of autosomal recessive syndromes associated with periodontitis. Material and Methods: An internet search using Google and PubMed search engine and keywords- autosomal recessive, periodontitis, syndromes, periodontium and gingiva was carried out. Full-text articles in the English language of all the case reports and reviews that were published in journals from the year 1966 to 2016 were obtained and evaluated and presented in tabular form. Abstracts and articles published in other languages were not included in the review. Results: The data available from the clinical trials were analyzed and presented under broad headings of, systemic features, dental features, periodontal features and laboratory findings presented in tabular

form. Conclusion: Many autosomal recessive syndromes with dental component also present with changes or alteration in the periodontium thus stressing the fact that thorough periodontal examination is important during the medical evaluation of patients with syndromes
\end{abstract}

\section{KEYWORDS}

Syndromes; Autosomal recessive; Periodontitis; Periodontium; Gingiva.

\section{RESUIMO}

Objetivo: Analisar sistematicamente os dados e resultados de relatos de caso de síndromes autossômicas recessivas associadas à periodontite. Material e Métodos: realizou-se uma pesquisa na internet usando os sites Google e PubMed com as palavras-chave: autossômica recessiva, periodontite, síndromes, periodonto e gengiva. Os critérios de inclusão foram restritos aos artigos em texto completo em língua inglesa, relatos de casos e revisões publicados em periódicos de 1966 a 2016. Resumos e artigos publicados em outras línguas não foram incluídos na revisão. Resultados: Os dados extraídos de cada estudo foram agrupados da seguinte forma: as síndromes associadas a características sistêmicas, aos achados dentários e aos achados periodontais, apresentados no formato de tabelas. Conclusões: Diversas síndromes autossômicas recessivas que apresentam alterações dentárias também podem apresentar alterações no periodonto, ressaltando assim, o fato de que o exame periodontal completo é importante durante a avaliação médica de pacientes com síndromes.

\section{PALAVRAS-CHAVE}

Síndromes; Autossômica recessiva; Periodontite; Periodonto; Gengiva. 


\section{INTRODUCTION}

A syndrome is defined as the collection of signs and symptoms associated with any morbid process and constituting together the picture of the disease. [1] Multiple manifestations could be caused by underlying developmental or metabolic conditions. Diagnosing and distinguishing a syndrome from other pathologies is challenging for a clinician. All syndromes have genetic components. Mutations in various classes of genes lead to craniofacial, dental and oro-facial defects. [1-5].

Some are more obviously important than others depending on the age of onset of the disease, degree of mental or physical impairment, number of affected persons and cost of care. Although many of these disorders are not preventable or curable early detection may allow significant improvement in health care. [25] Dentist is usually in a position to recognize a previously unrecognized genetic or birth defect problem in a patient or family. Since many syndromes affect the oral structures in a unique way it aids in diagnosis. Although treatment of genetic diseases is not yet available, maintenance of good oral health is important. [6]

Syndromes are classified as autosomal dominant, autosomal, recessive or sex-linked.

Identification of these syndromes and genetic counseling plays an important role in the prevention of progression of these syndromes to the next generation. In ideal situations of an autosomal dominant case, it is possible to trace the disorder through successive generations of the family and on an average equal number of males and females will be affected. In some conditions, the disease may skip generations in these situations the normal individual is assumed to have inherited the mutant gene but do not express it. This is referred to as incomplete penetrance. [1] In other cases, there may be a number of abnormalities with different individuals within a family exhibiting one or more of these abnormalities. This is referred to variable expression of the trait and it is possible to have a condition which exhibits both incomplete as well as variable expression. The periodontium is affected in some of the syndromes and identification of periodontal manifestations plays a vital role in the diagnosis of syndromes itself. In this review, an attempt has been made to review autosomal recessive syndromes of periodontal interest. In autosomal recessive inheritance, two copies of a disease allele are required for an individual to be susceptible to expressing the phenotype. (With an autosomal recessive condition, a gene alteration needs to be present in both copies of a particular gene to cause sufficient impairment to cell function to cause disease. The alterations are located on an autosome. A person with an autosomal recessive condition must have inherited one gene alteration from each parent. In autosomal recessive inheritance, people with one copy of the gene alteration do not have the condition. They are said to be carriers for the autosomal recessive condition.[2-6] Typically, the parents of an affected individual are not affected but are gene carriers.

Many of these cases are rare and thus the evidence comprising is mainly on case reports rather than epidemiological studies. However, it is relevant to consider syndromes background to these severe periodontal cases as it may eventually be relevant to treat and also to understand the pathogenesis of periodontitis in these patients.

\section{METHODOLOGY}

An internet search using Google and PubMed search engine and keywords- autosomal recessive, periodontitis, syndromes, periodontium and gingiva was carried out. Inclusion criteria were restricted to full-text articles in English language, case reports and reviews that were published in journals from the year 1966 to 2016. The articles were reviewed and presented in tabular form. Articles published in languages other than English were not included in this review. Abstracts were not included in the review. The data extracted from each study were grouped as follows: syndromes associated with systemic features, dental and periodontal findings are presented in the tabular format. [Table 1] 
Table 1 - Autosomal recessive syndromes with systemic, dental, and periodontal features

\begin{tabular}{|c|c|c|c|c|}
\hline Sl. & Syndrome & Systemic Features & Dental Features & Periodontal Features \\
\hline 1 & $\begin{array}{l}\text { Alport } \\
\text { Syndrome } \\
\text { (AS) [7] }\end{array}$ & $\begin{array}{l}\text { Hematuric nephropathy, renal failure, hearing loss, } \\
\text { ocular abnormalities and changes in the glomerular } \\
\text { basement membrane of the lamina densa. }\end{array}$ & No dental features reported & Gingival Hyperplasia \\
\hline 2 & $\begin{array}{l}\text { Bardet-Biedl } \\
\text { Syndrome } \\
\text { (BBS) [8] }\end{array}$ & $\begin{array}{l}\text { Retinitis, pigmentosa, polydactyly, obesity, genital } \\
\text { hypoplasia, mental retardation and renal disease. }\end{array}$ & $\begin{array}{l}\text { Hypodontia/small roots/high arched } \\
\text { palate/small teeth }\end{array}$ & $\begin{array}{l}\text { Generalized gingival overgrowth, General- } \\
\text { ized gingivitis. }\end{array}$ \\
\hline 3 & $\begin{array}{l}\text { Cross } \\
\text { Syndrome } \\
\text { (CS) }[2-6]\end{array}$ & $\begin{array}{l}\text { White hair, blond skin; melanocytes decreased with } \\
\text { reduced tyrosine activity; mental retardation; very rare. }\end{array}$ & No dental features reported & Gingival and alveolar enlargement, \\
\hline 4 & $\begin{array}{l}\text { Chediak- } \\
\text { Higashi } \\
\text { syndrome } \\
\text { (CHS)[9-11] }\end{array}$ & $\begin{array}{l}\text { Partial oculocutaneous albinism usually involving the } \\
\text { skin, eyes and hair. Susceptibility to infection, Photopho- } \\
\text { bia, frequent pyogenic infections and lymphadenopathy. }\end{array}$ & $\begin{array}{l}\text { Oral ulcerations } \\
\text { Prolonged bleeding times, ulcer- } \\
\text { ations of the tongue and buccal } \\
\text { mucosa, }\end{array}$ & $\begin{array}{l}\text { Severe horizontal bone loss early onset } \\
\text { periodontitis leading to premature loss of } \\
\text { both deciduous and permanent dentitions }\end{array}$ \\
\hline 5 & $\begin{array}{l}\text { Göhlich- } \\
\text { Ratmann } \\
\text { Syndrome } \\
\text { (GRS) [12] }\end{array}$ & $\begin{array}{l}\text { Mental retardation and epilepsy, brachymetacarpalia, } \\
\text { hirsutism, bulbous soft nose, thick floppy ears with } \\
\text { abnormal configuration. Brachymetacarpia, Tetralogy of } \\
\text { Fallot and the other with congenital hypothyroidism and } \\
\text { bilateral ureteral stenosis. }\end{array}$ & No dental features reported & Gingival hypertrophy \\
\hline 6 & $\begin{array}{l}\text { Haim-Munk } \\
\text { Syndrome } \\
\text { (HMS)[13-15] }\end{array}$ & $\begin{array}{l}\text { Inactivation of cathepsinC,Palmoplantar hyperkeratosis, } \\
\text { acro-osteolysis, atrophic changes of the nails, and a } \\
\text { radiographic deformity of the fingers. } \\
\text { Arachnodactyly (spider fingers), and pes planus (flat foot). }\end{array}$ & No dental findings & $\begin{array}{l}\text { Severe early-onset periodontitis that } \\
\text { affects both primary and permanent } \\
\text { dentitions, with severe alveolar bone } \\
\text { destruction }\end{array}$ \\
\hline 7 & $\begin{array}{l}\text { Hurler's } \\
\text { Syndrome } \\
\text { (HS) }[16,17]\end{array}$ & $\begin{array}{l}\text { A defect in genetically controlled pathways of lyso- } \\
\text { somal degradation. Physical and mental deterioration }\end{array}$ & $\begin{array}{l}\text { Primary teeth hypoplastic with } \\
\text { pitting of enamel. } \\
\text { The high-arched palate, anterior } \\
\text { open bite, Macroglossia, Hypoplastic } \\
\text { mandibular condyles }\end{array}$ & $\begin{array}{l}\text { Bone destruction surrounding unerupted } \\
\text { permanent teeth. }\end{array}$ \\
\hline 8 & $\begin{array}{l}\text { Kindler } \\
\text { Syndrome } \\
\text { (KS)[18-20] }\end{array}$ & $\begin{array}{c}\text { Skin fragility, patchy hyperpigmentation, hyperkeratosis } \\
\text { of palms and soles, diffuse skin wrinkling. } \\
\text { sun sensitivity, eczematoid dermatitis, skin fragility, } \\
\text { patchy }\end{array}$ & $\begin{array}{l}\text { Atrophy of buccal mucosa, limited } \\
\text { mouth opening, malocclusion, } \\
\text { erosion of hard palate, geographic } \\
\text { tongue, }\end{array}$ & $\begin{array}{l}\text { Bleeding, gingival swelling, desquamative } \\
\text { gingivitis. Patients present with severe } \\
\text { periodontitis of both the primary and } \\
\text { secondary dentition, resulting in severe } \\
\text { alveolar bone loss and premature exfolia- } \\
\text { tion of the teeth. }\end{array}$ \\
\hline 9 & $\begin{array}{l}\text { Kostmann } \\
\text { Syndrome(KS) } \\
\text { [21-25] }\end{array}$ & $\begin{array}{l}\text { Congenital neutropenia recurrent bacterial infections } \\
\text { early in life severe ear, skin, respiratory and oral infec- } \\
\text { tions, }\end{array}$ & $\begin{array}{l}\text { Severe oral infections, persistent } \\
\text { gingivitis }\end{array}$ & $\begin{array}{l}\text { Gingival swelling and bleeding, severe } \\
\text { inflammation of all gingival tissues and } \\
\text { periapical abscess with mobility, aggres- } \\
\text { sive periodontitis with alveolar bone loss. }\end{array}$ \\
\hline 10 & $\begin{array}{l}\text { Lazy } \\
\text { Leukocyte } \\
\text { Syndrome } \\
\text { (LLS)[26,27] }\end{array}$ & $\begin{array}{l}\text { Severe neutropenia, Recurring infection, deficiency in } \\
\text { neutrophil chemotaxis and systemic neutropenia, }\end{array}$ & $\begin{array}{l}\text { Painful stomatitis, gingivitis and } \\
\text { recurrent ulcerations of the buccal } \\
\text { mucosa and tongue }\end{array}$ & $\begin{array}{l}\text { Periodontitis progressing to the point of } \\
\text { advanced alveolar bone loss and tooth } \\
\text { loss has been reported. Individuals are } \\
\text { susceptible to aggressive periodontitis. }\end{array}$ \\
\hline 11 & $\begin{array}{l}\text { Maroteaux- } \\
\text { Lamy Syn- } \\
\text { drome (mu- } \\
\text { copolysac- } \\
\text { charidosis } \\
\text { VI) (MLS) } \\
{[28,29]}\end{array}$ & $\begin{array}{l}\text { A large head, short neck, corneal opacity, open mouth } \\
\text { associated with an enlarged tongue, enlargement of } \\
\text { the skull, and a long anteroposterior dimension bone } \\
\text { dysplasia, joint restriction, organomegaly, heart disease, } \\
\text { and corneal clouding, among several other problems, } \\
\text { and reduced life span. }\end{array}$ & $\begin{array}{l}\text { Unerupted dentition, dentiger- } \\
\text { ous cyst follicles, malocclusions, } \\
\text { condylar defects. } \\
\text { High palate, open bite } \\
\text { Impacted and/or included teeth, } \\
\text { thickening of the pericoronal follicle, } \\
\text { and changes in the temporoman- } \\
\text { dibular joint. }\end{array}$ & Gingival hyperplasia. \\
\hline
\end{tabular}




\begin{tabular}{|c|c|c|c|c|}
\hline Sl. & Syndrome & Systemic Features & Dental Features & Periodontal Features \\
\hline 12 & $\begin{array}{c}\text { Murray-Puretic } \\
\text { Drescher Syn- } \\
\text { drome (MPDS) } \\
\text { [30] }\end{array}$ & $\begin{array}{l}\text { Suppurative lesions of the skin and mucosa; flexion } \\
\text { contractures mental retardation; elevated urinary } \\
\text { dermatan sulfate. } \\
\text { Growth retardation, gingival hypertrophy, joint contrac- } \\
\text { tures and skin lesions. }\end{array}$ & No dental features reported & Gingival fibromatosis. \\
\hline 13 & $\begin{array}{l}\text { Papillon-Lefe- } \\
\text { vre Syndrome } \\
\text { (PLF) [31-34] }\end{array}$ & $\begin{array}{c}\text { Cathepsin C. Inactivation of cathepsin C results in } \\
\text { failures to cleave and activate the neutrophil serine } \\
\text { proteases cathepsin G, neutrophil elastase, and } \\
\text { proteinase Palmoplantar hyperkeratosis, palmoplantar } \\
\text { hyperkeratosis }\end{array}$ & No dental features reported & $\begin{array}{l}\text { Severe early-onset periodontitis that } \\
\text { affects both primary and permanent } \\
\text { dentitions. } \\
\text { alveolar bone loss severe aggressive } \\
\text { periodontitis, premature tooth loss } \\
\text { generalized rapid destruction of the } \\
\text { periodontal attachment apparatus } \\
\text { resulting in premature loss of both } \\
\text { primary and permanent teeth. }\end{array}$ \\
\hline 14 & $\begin{array}{l}\text { Ramon Syn- } \\
\text { drome[2-5,35] }\end{array}$ & $\begin{array}{l}\text { Juvenile rheumatoid arthritis. Epilepsy, mental retarda- } \\
\text { tion, hypertrichosis, and stunted growth. }\end{array}$ & $\begin{array}{l}\text { Cherubism, radiolucent lesions of } \\
\text { mandible and Maxilla, persistent an- } \\
\text { terior fontanelle, fibrous dysplasia, } \\
\text { buried teeth, narrow palate, delayed } \\
\text { tooth eruption }\end{array}$ & Gingival fibromatosis \\
\hline 15 & $\begin{array}{l}\text { Rutherford syn- } \\
\text { drome[2-5,36] }\end{array}$ & $\begin{array}{l}\text { Mental retardation, aggressive behavior, dentigerous } \\
\text { cysts; only one kindred reported. }\end{array}$ & No dental features reported & $\begin{array}{l}\text { Congenitally enlarged gingivae, } \\
\text { delayed tooth eruption, "curtain-like" } \\
\text { superior corneal opacities. }\end{array}$ \\
\hline 16 & $\begin{array}{c}\text { Winchester } \\
\text { Syndrome (WS) } \\
\text { [37] }\end{array}$ & $\begin{array}{l}\text { Short stature, coarse facial features, hyperpigmenta- } \\
\text { tion, or excessive hair growth. }\end{array}$ & No dental features reported & Gingival Enlargement \\
\hline
\end{tabular}

\section{RESULTS}

The autosomal recessive syndromes discussed within the scope of this review areAlport syndrome, Bardet-Biedl syndrome, Cross syndrome, Chediak-Higashi syndrome Göhlich-Ratmann syndrome, Haim-Munk syndrome, Hurler's Syndrome, Kindler syndrome Kostmann syndrome, Lazy Leukocyte Syndrome, Maroteaux-Lamy syndrome, Murray-Puretic Drescher syndrome, Papillon-Lefevre syndrome, Ramon Syndrome and Rutherford syndrome. All the above mentioned autosomal recessive conditions have significant dental and periodontal findings as stated in the table. Some of the aggressive periodontal features might lead to tooth loss which in turn may further deteriorate the quality of life in these individuals. On the evaluation of the tabular data, the oral features of the syndromes followed three patterns. In the first pattern, only periodontal findings are observed with no distinct dental features or mucosal features. The syndromes with only periodontal/gingival findings without dental hard tissue findings include Alport syndrome, Cross syndrome, Golich Ratman syndrome, Haim-Munk syndrome, Murray-Puretic Drescher syndrome, Papillon Lefevre syndrome, Rutherford syndrome and Winchester syndrome. In the second pattern of clinical features, the syndromes included both hard tissue and periodontal findings. The syndromes in with this feature include Maroteaux-Lamy syndrome, Hurlers syndrome and Bardet-Biedl syndrome. The third pattern observed in the oral features of the syndromes mentioned in the table is a combination of oral mucosal features and periodontal/ gingival findings. The syndrome that occurs in this category is Lazy Leukocyte syndrome, Kostmann syndrome, Kindler syndrome and Chedialk Higashi syndrome. 


\section{DISCUSSION}

Apart from classifying the syndromes based on the combination of periodontal/ gingival, dental and mucosal findings the syndromes can also be classified under the following categories, namely. The syndromes listed above have been discussed under the three categories namely-

- Syndromes associated with gingival findings- Alport Syndrome, Bardet-Biedl Syndrome, Göhlich-Ratmann syndrome, Maroteaux-Lamy syndrome, Murray-Puretic Drescher syndrome, Ramon Syndrome, Rutherford syndrome.

- Syndromes associated with gingival and periodontal findings- Cross syndrome, Haim-Munk syndrome, Kostman syndrome, Papillon-Lefevre syndrome.

- Syndromes associated with dental, gingival and periodontal findings- ChediakHigashi syndrome, Hurler's Syndrome, Kindler syndrome, Lazy Leukocyte Syndrome.

Alport Syndrome: The mutation presented in AS produces defects in chains $\alpha 3$, $\alpha 4$, and $\alpha 5$ (IV) of Type IV collagen which is an important component of the periodontium. This defect leads to disruptions of the epithelial bonds leading to gingival hyperplasia which appears as a prominent intraoral finding in this syndrome. [38]

Bardet-Biedl Syndrome (BBS): The syndrome is characterized by the six main general clinical features. Oral findings that have been frequently associated with this syndrome include hypodontia, small roots, high arched palate, microdontia and gingival enlargement. [39]

\section{Maroteaux-Lamy syndrome (MLS):} The intraoral finding associated with of this syndrome include gingival hyperplasia, hypertrophy of the maxillary alveolar ridge, macroglossia, unerupted dentition, malocclusions and dentigerous cyst-like follicles. [40]
Murray Puretic Drescher SyndromeJHF: Juvenile Hyaline Fibromatosis is characterized by disproportionate accumulation for hyalin in various tissues such as skin, stomach-intestinal system, heart muscle, surrenals, skeletal muscles, spleen, and lymph nodes thyroid tissue. Gingival hypertrophy is very prevalent and distinctive oral finding in this syndrome. Some cases of advanced gingival hypertrophy have caused difficulties in tracheal intubation. Presence of cervical spine and temporomandibular joint contractures further adds to the difficulty in the tracheal intubation procedure. [41]

Ramon's Syndrome (RS): Gingival fibromatosis (GF) associated with Ramon's syndrome could be attributed to the adverse effect of the anti-epileptic drug often used as a treatment modality for seizures associated with this syndrome. However, there are cases with sporadic occurrence of fibromatosis often in the absence of seizures or use of antiepileptic drugs. The characteristic feature of occurrence of fibromatosis is its coincidence with the eruption of teeth. [2-5,42,43]

Rutherford syndrome (RS): The association of gingival fibromatosis with corneal opacities and retarded tooth eruption is recognized as an autosomal dominant trait known as Rutherfurd syndrome. [2-5]

Winchester syndrome (WS): Winchester Syndrome is often attributed to alteration in a gene called MMP2. It is suggested that this condition is caused by a nonlysosomal connective-tissue alteration. The protein inactivation mutation is found on the matrix metalloproteinase 2 gene (MMP2) MM2 which is responsible for bone remodeling. This alteration in the pattern of bone remodeling leads to periodontal tissue destruction. [37,44]

Cross Syndrome (CS): Cross syndrome is, almost certainly, an autosomal recessive disorder characterized by gingival fibromatosis, microphthalmia, mental retardation, athetosis, and hypopigmentation. [2-5] 
Haim-Munk Syndrome (HMS): HaimMunk syndrome is an exceedingly rare autosomal recessive disorder characterized clinically by palmoplantar hyperkeratosis, aggressive periodontitis with severe alveolar bone destruction. The other key features of the syndrome are onychogryphosis, pes planus, arachnodactyly, and acro-osteolysis. A definite link to the history of consanguinity seems to be responsible in all documented cases. Presence of typical dermatological, periodontal, and radiological features are generally important for the diagnosis of this syndrome. A classic distinguishing feature between HMS and Papillon-Lefever syndrome [PLS] is that the severity of the periodontal destruction is less severe in later. [14,42] Early diagnosis seconded by prompt intervention often leads to better retention of permanent teeth.

Papillon-Lefever syndrome: The key features of PLS consist of severe gingivastomatitis and periodontitis. No changes have been reported in the literature regarding eruption pattern or sequence associated with primary teeth. However morphological alteration such as microdontia, root resorption, and incomplete root formation have been reported frequently. Vertical bone loss at a younger age is the common radiographic feature observed in most of published case reports. [46]

Chediak-Higashi syndrome: Severe gingivitis and gingival bleeding accompanied by early tooth loss are the commonly reported oral features of CHS. Premature tooth loss in this syndrome could be attributed to alveolar bone loss secondary to inflammation associated with periodontal pathogens such as Prophyromonas gingivalis, Prevoteua intermedia and Tannerella forsythia. Aphthous, pyoderma and oral ulcer have sometimes been reported in cases of CHS. [47]

Hurler's syndrome: Hurler's syndrome also referred to as mucopolysaccharidosis type $\mathrm{IH}$ is an autosomal-recessive inherited disorder. It often signifies the classical prototype of a mucopolysaccharide disorder. [48,49] The oral and dental findings of MPS I-II comprise of hyperplastic gingiva, macroglossia, higharched palate, short mandibular rami with abnormal condyles, spaced hypoplastic peg-shaped teeth with a retarded eruption. Dental radiographic features such as localized cyst-like radiolucencies often mimicking dentigerous cyst have been reported. [49]

Kindler syndrome: The syndrome is frequently associated with aggressive periodontitis leading to tooth loss. desquamative gingivitis along with gingival bleeding also have been noticed in some case reports. [50]

Lazy leukocyte syndrome: Oral mucosal findings such as excruciating pain associated stomatitis often recurrent ulcerations have been observed. Gingivitis and periodontitis progress to the point of advanced alveolar bone loss and tooth loss has been reported. [51]

\section{CONCLUSION}

Genetics will endure and dictate dental, medical diagnostics in the future. Human and microbial genomics proteonomics and metabolomics added with pharmacogenomics will shape the future of the medical profession. All dentist and physicians need to comprehend the concepts of genetic variability, its interface with the environment and its repercussions for the patient and population healthcare. In the near future genomics will augment preventive, diagnostics and therapeutics. Few reviews articles, in general, have discussed the dental and periodontal features of syndromes. However, in this review, an attempt has been made to discuss very specifically the periodontal and dental features of autosomal recessive syndromes. A number of autosomal recessive syndromes and the details of dental and periodontal features have been discussed in the above review making it a fairly useful article for a clinician or researcher looking out for comprehensive data on this specific topic. The results obtained from the review also aid 
in categorizing the syndromes based on the presence of dental periodontal and mucosal features. This categorization reduces the number of syndromes in the list of differential diagnosis and aids in the diagnosis of these syndromes which are rare in occurrence.

\section{REFERENCES}

1. Jones KL. Smith's recognizable patterns of human manifestations. In 6th edit. Elsevier, Philadelphia.2006.1-4.

2. Aldred MJ, Artold PM. Genetic disorders of the gingivae and periodontium. Periodontol 2000. 1998 0ct;18:7-20.

3. Hart TC, Pallos D, Bozzo L, Almeida OP, Marazita ML, O'Connell JR, et al. Evidence of genetic heterogeneity for hereditary gingival fibromatosis. J Dent Res. 2000 0ct;79(10):1758-64.

4. Coletta RD, Graner E. Hereditary gingival fibromatosis: a systematic review. J Periodontol. 2006 May;77(5):753-64.

5. Poulopoulos A, Kittas D, Sarigelou A. Current concepts on gingival fibromatosis-related syndromes. J Investig Clin Dent. 2011 Aug;2(3):156-61. doi: 10.1111/.j.2041-1626.2011.00054.x. Epub 2011 Mar 15.

6. Gorlin RJ, Pindborg JJ. Syndromes of the head and neck. New York: Mc-Graw Hill; 1964. 1105 p.

7. Toygar HU, Toygar O, Guzeldemir E, Cilasun U, Nacar A, Bal N. Alport Syndrome: Significance of gingival Biopsy in the initial diagnosis and periodontal Evaluation after renal transplantation. J Appl Oral Sci. 2009 Nov-Dec;17(6):623-9.

8. Drugowick RM, Da Rós Gonçalves L, Barrôso AS, Feres-Filho EJ, Maia LC. Treatment of Gingival Overgrowth in a Child with Bardet-Biedl Syndrome. J Periodontol. 2007 Jun;78(6):1159-63.

9. Rezende KM, Canela AH, Ortega AO, Tintel C, Bönecker M. Syndrome and Premature Exfoliation of Primary Teeth. Braz Dent J. 2013 NovDec;24(6):667-70. doi: 101590/0103-6440201302258.

10. Khocht A, Viera-Negron YE, Ameri A, Abdelsayed R. Periodontitis associated with Chediak-Higashi syndrome in a young African American male. J Int Acad Periodontol. 2010 Apr;12(2):49-55.

11. Bailleul-Forestier I, Monod-Broca J, Benkerrou M, Mora F, Picard B. Generalized Periodontitis associated with Chediak-Higashi syndrome. J Periodontol. 2008 Jul;79(7):1263-70. doi: 10.1902/jop.2008.070440.

12. Göhlich-Ratmann G, Lackner A, Schaper J, Voit T, Gillessen-Kaesbach G. Syndrome of gingival hypertrophy, hirsutism, mental retardation and brachymetacarpia in two sisters: specific entity or variant of a described condition? Am J Med Genet. 2000 Nov 27;95(3):241-6.

13. Rai R, Thiagarajan S, Mohandas S, Natarajan K, Shanmuga Sekar C, Ramalingam S. Haim Munk syndrome and Papillon Lefevre syndrome-allelic mutations in cathepsin $\mathrm{C}$ with variation in phenotype. Int $\mathrm{J}$ Dermatol. 2010 May;49(5):541-3. doi: 10.1111/j.1365-4632.2010.04300.x.

14. Hart TC, Hart PS, Michalec MD, Zhang Y, Firatli E, Van Dyke TE, et al. Haim-Munk syndrome and Papillon-Lefèvre syndrome are allelic mutations in cathepsin C. J Med Genet. 2000 Feb;37(2):88-94.

15. Hart TC, Stabholz A, Meyle J, Shapira L, Van Dyke TE, Cutler CW, et al. Genetic studies of syndromes with severe periodontitis and palmoplantar hyperkeratosis. J Periodontal Res. 1997 Jan;32(1 Pt 2):81-9.
16. Sharma S, Sabharwal JR, Datta P Sood S. Clinical manifestation of Hurler syndrome in a 7-year-old child. Contemp Clin Dent. 2012 Jan;3(1):86-9. doi: 10.4103/0976-237X.94554.

17. Tatapudi R, Gunashekhar M, Raju PS. Mucopolysaccharidosis type Hurler-Scheie syndrome: A rare case report. Contemp Clin Dent. 2011 Jan;2(1):66-8. doi: 10.4103/0976-237X.79287.

18. Wiebe CB, Petricca G, Häkkinen L, Jiang G, Wu C, Larjava HS. Kindler syndrome and periodontal disease: review of the literature and a 12year follow-up case. J Periodontol. 2008 May;79(5):961-6. doi: 10.1902/ jop.2008.070167.

19. Wiebe CB, Penagos H, Luong N, Slots J, Epstein E Jr, Siegel D, et al. Clinical and microbiologic study of periodontitis associated with Kindler syndrome. J Periodontol. 2003 Jan;74(1):25-31.

20. Wiebe CB, Silver JG, Larjava HS. Early-onset periodontitis associated with Weary-Kindler syndrome: a case report. J Periodontol. 1996 0ct;67(10):1004-10.

21. Gonzalez S, Frydman A. The non-surgical management of a patient with Kostmann syndrome-associated periodontitis: a case report. J Oral Sci. 2014 Dec;56(4):315-8.

22. Salehi T, Fazlollahi MR, Maddah M, Nayebpour M, Yazdi MT, Alizadeh $Z$, et al. Prevention and Control of Infections in Patients with Severe Congenital Neutropenia; A Follow up Study. Iran J Allergy Asthma Immunol. 2012 Mar;11(1):51-6. doi: 011.01/ijaai.5156.

23. Ye Y, Carlsson G, Wondimu B, Fahlén A, Karlsson-Sjöberg J, Andersson M, et al. Mutations in the ELANE Gene are Associated with Development of Periodontitis in Patients with Severe Congenital Neutropenia. J Clin Immunol. 2011 Dec;31(6):936-45. doi: 10.1007/ s10875-011-9572-0. Epub 2011 Jul 29.

24. Hakki SS, Aprikyan AA, Yildirim S, Aydinbelge M, Gokalp A, Ucar $C$, et al. Periodontal status in two siblings with severe congenital neutropenia: diagnosis and mutational analysis of the cases. J Periodontol. 2005 May;76(5):837-44.

25. Lalwani M, Suchetha A, Mundinamane DB, Sapna N, Bhat D, Jayachandran C. Neutrophil associated syndromes and periodontitis. J Chem Pharm Res. 2016;8(2):421-7.

26. Aggarwal J, Khan AJ, Diamond S, Schaeffer HA, Evans HE. Lazy leukocyte syndrome in a black infant. J Natl Med Assoc. 1985 Nov;77(11):928-9.

27. Goldman JM, Foroozanfar N, Gazzard BG, Hobbs JR. Lazy leukocyte syndrome. J R Soc Med. 1984 Feb;77(2):140-1.

28. Alpöz AR, Coker M, Celen E, Ersin NK, Gökçen D, van Diggelenc $\mathrm{OP}$, et al. The oral manifestations of Maroteaux-Lamy syndrome (mucopolysaccharidosis VI): a case report. Oral Surg Oral Med Oral Pathol Oral Radiol Endod. 2006 May;101(5):632-7. Epub 2006 Mar 3.

29. Guimarães Mdo C, de Farias SM, Costa AM, de Amorim RF. MaroteauxLamy syndrome: orofacial features after treatment by bone marrow transplant. Oral Health Prev Dent. 2010;8(2):139-42.

30. Sciubba JJ, Niebloom T. Juvenile hyaline fibromatosis (Murray-PureticDrescher syndrome): oral and systemic findings in siblings. Oral Surg Oral Med Oral Pathol. 1986 0ct;62(4):397-409.

31. AlBarrak ZM, Alqarni AS, Chalisserry EP, Anil S. Papillon-Lefèvre syndrome: a series of five cases among siblings. J Med Case Rep. 2016 Sep 22;10(1):260.

32. Pavankumar K. Papillon-Lefevre syndrome: A case report. Saudi Dent J. 2010 Apr;22(2):95-8. doi: 10.1016/j.sdentj.2010.02.009. Epub 2010 Feb 6. 
33. Hart TC, Hart PS, Bowden DW, Michalec MD, Callison SA, Walker SJ, et al. Mutations of the cathepsin $\mathrm{C}$ gene are responsible for PapillonLefèvre syndrome. J Med Genet. 1999 Dec;36(12):881-7.

34. Paghdiwala AF. Papillon-Lefèvre syndrome: a case report. J Periodontol. 1980 0ct;51(10):594-8.

35. Parkin B, Axenfeld CL. Anomaly and retinal changes in ramon syndrome: follow-up of two sibs. Am J Med Genet. 2001 Nov 22;104(2):131-4

36. Houston I, Shoots N. Rutherford's syndrome a familial oculodenta disorder. Acta Ped Scand 1966;55:233-237.

37. Ekbote AV, Danda S, Zankl A, Mandal K, Maguire T, Ungerer K. Patient with Mutation in the Matrix Metalloproteinase 2 (MMP2) Gene - A Case Report and Review of the Literature. J Clin Res Pediatr Endocrinol. 2014;6(1):40-6. doi: 10.4274/Jcrpe.1166.

38. Hudson BG, Tryggvason K, Sundaramoorthy M, Neilson EG. Alport's syndrome, Good pasture's syndrome, and type IV collagen. N Engl J Med. 2003 Jun 19;348(25):2543-56.

39. Majumdar U, Arya G, Singh S, Pillai A, Nair PP. Oro-dental findings in Bardet-Biedl syndrome. BMJ Case Rep. 2012 Apr 23;2012. pii: bcr1220115320. doi: 10.1136/bcr.12.2011.5320.

40. Guimarães Mdo C, Farias SM, Costa AM, Amorim RF. MaroteauxLamy syndrome: Orofacial features after treatment by bone marrow transplant. Oral Health Prev Dent. 2010;8(2):139-42.

41. Onal O, Saltali A, Cepnikutahya E, Bozdogan S, Celik JB. Anestesia management in juvenile hyaline fibromatosis (JHF-Murray Puretic Drescher Syndrome). Surgery Curr Res. 2014;4(6):177. doi: 10.4172/2161-1076.S1.018

42. Luke A, Peter S, Nampoothiri S, Rao L, Nambiar A, Veeraraghavan R, et al. Ramon's Syndrome: A Rare Entity. World J Dent. 2010;1(3):199-204. doi: 10.5005/jp-journals-10015-1039.
43. Suhanya J, Aggarwal C, Mohideen K, Jayachandran S, Ponniah I. Cherubism combined with epilepsy, mental retardation and gingival fibromatosis (Ramon syndrome): a case report. Head Neck Pathol. 2010 Jun;4(2):126-31. doi: 10.1007/s12105-009-0155-9. Epub 2009 Dec 11.

44. Ekbote AV, Danda S, ZankI A, Mandal K, Maguire T, Ungerer K. Patient with mutation in the matrix metalloproteinase 2 (MMP2) gene - a case report and review of the literature. J Clin Res Pediatr Endocrinol. 2014;6(1):40-6. doi: 10.4274/Jcrpe.1166

45. Erciyas K, Inaloz S, Erciyas AF. Periodontal Manifestations in a Patient with Haim-Munk Syndrome. Eur J Dent. 2010 Jul;4(3):338-40.

46. Sreeramulu B, Shyam ND, Ajay P, Suman P. Papillon-Lefèvre syndrome: clinical presentation and management options. Clin Cosmet Investig Dent. 2015 Jul 15:7:75-81. doi: 10.2147/CCIDE.S76080. eCollection 2015.

47. Ghaffari J, Rezaee SA, Gharagozlou M. Chédiak-Higashi syndrome. J Pediatr Rev. 2013;1(2):80-7.

48. Shetty RM, Dixit U, Hegde R, Shivprakash PK. RURS' elbow guard an innovative treatment of the thumb-sucking habit in a child with Hurler's syndrome. J Indian Soc Pedod Prev Dent. 2010 JulSep;28(3):212-8. doi: 10.4103/0970-4388.73796.

49. Guven G, Cehreli ZC, Altun C, Sençimen M, Ide S, Bayari SH, et al. Mucopolysaccharidosis type I (Hurler syndrome): oral and radiographic findings and ultrastructural/chemical features of enamel and dentin. Oral Surg Oral Med Oral Pathol Oral Radiol Endod. 2008 Jan;105(1):72-8. Epub 2007 Jun 29.

50. Moradihaghgoo TP, Gholami SB, Sabzeghabaie ML, Faramarzi F, Shams N. Periodontal Management of a Patient with Kindler Syndrome. AJDR. 2012:4(2):67-71.

51. Lalwani M, Suchetha A, Mundinamane DB, Sapna N, Bhat D, Jayachandran C. Neutrophil associated syndromes and periodontitis. Journal of Chemical and Pharmaceutical Research 2016;8(2):421-7.

\section{Dr. Sesha Reddy}

\section{(Corresponding address)}

Department of Periodontics, College of Dentistry

Gulf medical university, Ajman, United Arab Emirates

Date submitted: 2018 Jan 06

Mail: drshishirshettyomr@yahoo.com 